\title{
PENGARUH KINERJA MENGAJAR GURU DAN IKLIM SEKOLAH TERHADAP PRESTASI BELAJAR SISWA (Studi Deskriptif di MI Kelompok Kerja Madrasah Cipaku)
}

\author{
Lilis Kholisoh', Maman Herman' ${ }^{2}$ Enas $^{3}$ \\ Universitas Galuh Ciamis
}

\begin{abstract}
This study aims to determine: 1) The effect of teacher teaching performance on student achievement. 2) The influence of school climate on student achievement. 3) The effect of teacher teaching performance and school climate on student learning achievement. The research method used in the preparation of this scientific paper is descriptive. The unit of analysis is a school with a total of 171 respondents. The data were proceeded by using SPSS 17.0. The study results show that: 1) The teaching performance of teachers at MI KKM Cipaku is in high criteria, however, some indicators need to be improved, namely arranging seats according to the characteristics of students and subjects. Furthermore, the teacher's teaching performance has a positive effect on student achievement. This means that the higher the teacher's teaching performance, the higher the student's learning achievement. 2) The school climate at MI KKM Cipaku is in conducive criteria, however, some indicators need to be improved, namely monumental evidence of the results of the school's collaboration with the community. Furthermore, the school climate has a positive effect on student achievement. This means that the more conducive the school climate, the more students' learning achievement. 3) Student achievement at KKM Cipaku is in the achievement criteria, however, several indicators must be improved, namely youth scientific work, academic competitions, sports, arts, and scouts. Furthermore, teacher teaching performance and school climate have a positive effect on student learning achievement. This means that the higher the teacher's teaching performance and the more conducive the school climate, the higher the student's learning achievement.
\end{abstract}

Keywords: Teacher Teaching Performance, School Climate, Student Achievement

\section{PENDAHULUAN}

Undang-undang RI Nomor 20 Tahun 2003, pasal 3 ayat (6) bahwa pendidikan diselenggarakan sebagai suatu proses pembudayaan dan pemberdayaan peserta didik yang berlangsung sepanjang hayat. Pada kenyataannya bahwa, pendidikan belum sepenuhnya memberikan pencerahan pada masyarakat melalui nilai manfaat dari pendidikan itu sendiri. Kenyataan ini dibuktikan dengan rendahnya kualitas lulusan. Pendidikan menjadi kawasan politisasi dari kalangan elit, bahkan yang lebih parah lagi perburuan proyek yang akibatnya pendidikan menjadi biasa. Masyarakat akan terus mempertanyakan mau dibawa ke mana pendidikan ini, karena relevansinya dengan kebutuhan masyarakat masih rendah. Bahkan menyiapkan sumber daya manusia melalui 
pendidikan sebagai penerus tidak memenuhi harapan masyarakat dan lebih ironisnya terjadi krisis moral sebagai bangsa bermartabat.

Rendahnya kualitas sumber daya manusia merupakan masalah mendasar yang dapat menghambat pembangunan dan perkembangan ekonomi nasional. Rendahnya kualitas sumber daya manusia juga akan menjadi batu sandungan dalam era globalisasi, karena era globalisasi merupakan era persaingan mutu. Jika bangsa Indonesia ingin berkiprah dalam percaturan global, maka langkah pertama yang harus dilakukan adalah menata sumber daya manusia, baik dari aspek intelektual, spiritual, kreativitas, moral, maupun tanggung jawab.

Penataan sumber daya tersebut perlu diupayakan secara bertahap dan berkesinambungan melalui sistem pendidikan yang berkualitas baik pada jalur pendidikan formal, informal, maupun non formal, mulai dari pendidikan dasar sampai pendidikan tinggi (Mulyasa 2004: 4). Dikatakan lebih lanjut oleh Mulyasa tentang pentingnya pengembangan sistem pendidikan yang berkualitas perlu lebih ditekankan, karena berbagai indikator menunjukkan bahwa pendidikan yang ada belum mampu menghasilkan sumber daya sesuai dengan perkembangan masyarakat dan kebutuhan pembangunan.

Pemerintah telah berusaha melakukan perbaikan-perbaikan agar mutu pendidikan meningkat, diantaranya dengan perbaikan kurikulum penataran bagi guru-guru, pemyempurnaan buku-buku pelajaran dan penambahan alat peraga. Namun demikian mutu pendidikan yang dicapai belum seperti apa yang diharapkan. Perbaikan yang telah dilakukan pemerintah tidak ada artinya, jika tanpa dukungan dari guru, orang tua siswa, siswa dan masyarakat yang turut serta dalam meningkatkan mutu pendidikan.

Berbicara tentang mutu pendidikan tidak akan lepas dari kegiatan belajar. Hasil kegiatan belajar yang diharapkan adalah prestasi belajar yang baik. Setiap orang pasti mendambakan prestasi belajar yang tinggi, baik orang tua, siswa dan lebih-lebih bagi guru. Untuk mencapai prestasi belajar yang optimal tidak lepas dari kondisi-kondisi dimana kemungkinan siswa dapat belajar dengan efektif dan dapat mengembangkan daya eksplorasinya baik fisik maupun psikhis. Memperoleh prestasi belajar yang baik tidaklah mudah, banyak faktor yang mempengaruhi. Faktor siswa memegang peranan dalam mencapai prestasi belajar yang baik, karena siswa yang melakukan kegiatan belajar perlu memiliki karakter belajar yang positif.

Proses belajar mengajar merupakan salah satu hal utama dalam menjawab semua permasalahan tersebut. Proses belajar mengajar tersebut ditopang oleh tiga komponen yaitu siswa, guru dan peralatan serta perlengkapan. Sardiman (2005: 125) mengemukakan guru adalah salah satu komponen manusiawi dalam proses belajar mengajar, yang ikut berperan dalam usaha pembentukan sumber daya manusia yang potensial di bidang pembangunan. Oleh karena itu, guru yang merupakan salah satu unsur di bidang kependidikan harus berperan secara aktif dan menempatkan kedudukannya sebagai tenaga profesional, sesuai dengan tuntutan masyarakat yang semakin berkembang. Dalam 
hal ini guru tidak semata-mata sebagai pengajar yang melakukan transfer ilmu pengetahuan, tetapi juga sebagai pendidik yang melakukan transfer nilai-nilai sekaligus sebagai pembimbing yang memberikan pengarahkan dan menuntun siswa dalam belajar.

Kelengkapan dari jumlah tenaga pengajar, dan kualitas dari guru tersebut akan mempengaruhi keberhasilan siswa dalam belajar, yang berujung pada peningkatan mutu pendidikan. Untuk itu guru dituntut lebih profesional dalam menjalankan tugasnya. Tugas Keprofesionalan Guru menurut Undang-Undang Republik Indonesia Nomor 14 Tahun 2005 pasal 20 (a) Tentang Guru dan Dosen adalah "Merencanakan pembelajaran, melaksanakan proses pembelajaran yang bermutu, serta menilai dan mengevaluasi hasil pembelajaran." Tugas pokok guru tersebut yang diwujudkan dalam kegiatan belajar mengajar serta tugas-tugas guru dalam kelembagaan marupakan bentuk kinerja guru. Apabila kinerja guru meningkat, maka berpengaruh pada peningkatan kualitas keluaran atau outputnya. Oleh karena itu perlu dukungan dari berbagai pihak sekolah untuk meningkatkan kinerja guru.

Untuk mengetahui kinerja mengajar guru di bawah ini disajikan data prestasi belajar siswa melalui nilai Ujian Akhir Semester (UAS) ganjil selama 4 tahun terakhir, seperti pada tabel 1.1 berikut ini:

Tabel 1.1

Nilai Rata-Rata Ujian Akhir Semeter (UAS) Ganjil MIN Muktisari Periode 2017/2018 s.d 2020/2021

\begin{tabular}{|c|l|c|c|c|c|}
\hline No & \multicolumn{1}{|c|}{ Nama } & $2017 / 2018$ & $2018 / 2019$ & $2019 / 2020$ & $2020 / 2021$ \\
\hline 1 & Akidah Akhlaq & 6,90 & 6,84 & 7,33 & 7,35 \\
\hline 2 & Qur'an Hadist & 6,25 & 6,19 & 5,92 & 6,00 \\
\hline 3 & SKI & 5,92 & 6,03 & 6,42 & 6,45 \\
\hline 4 & Bahasa Arab & 6,85 & 7,00 & 7,08 & 7,15 \\
\hline 5 & PKn & 6,95 & 7,05 & 7,15 & 7,20 \\
\hline 6 & Bahasa Indonesia & 6,75 & 6,95 & 7,05 & 7,12 \\
\hline 7 & IPA & 6,52 & 6,60 & 6,65 & 6,70 \\
\hline 8 & IPS & 6,65 & 6,75 & 6,80 & 6,85 \\
\hline 9 & Matematika & 6,90 & 7,10 & 7,15 & 7,25 \\
\hline 10 & Bahasa Inggris & 7,00 & 7,20 & 7,30 & 7,37 \\
\hline 11 & Bahasa Sunda & 6,77 & 6,85 & 6,90 & 6,95 \\
\hline
\end{tabular}




\begin{tabular}{|c|l|c|c|c|c|}
\hline 12 & SBK & 6,90 & 7,00 & 7,05 & 7,10 \\
\hline 13 & Penjaskes & 7,15 & 7,35 & 7,40 & 7,50 \\
\hline 14 & PLH & 7,00 & 7,20 & 7,30 & 7,37 \\
\hline & Jumlah & 94,51 & 96,11 & 97,50 & 98,36 \\
\hline & Rata-Rata & 6,75 & 6,87 & 6,96 & 7,03 \\
\hline
\end{tabular}

Sumber: MIN Muktisari, 2021

Berdasarkan tabel 1.1 dapat diketahui bahwa rata-rata nilai Ujian Akhir Semester Ganjil pada MIN Muktisari terjadi penurunan selama dua tahun terakhir pada mata pelajaran Qur'an Hadist sedangkan pada mata pelajaran lainnya mengalami peningkatan meskipun belum optimal. Dari data tersebut terjadinya penurunan pada mata pelajaran Qur'an Hadist serta meningkatnya nilai pada mata pelajaran lain dimungkinkan dipengaruhi oleh kinerja mengajar guru dan iklim organisasi. Hasil penelitian Listiani (2005:53) menunjukkan bahwa: "Secara simultan atau bersama-sama antara kinerja mengajar guru dan iklim sekolah berpengaruh terhadap prestasi belajar siswa kelas II SMK Negeri 5 Semarang sebesar 46,7\% sedangkan 53,3\% ditentukan faktor lain."

Kinerja mengajar guru akan menjadi optimal, bilamana diintegrasikan dengan komponen sekolah, baik itu kepala sekolah, iklim sekolah, guru, karyawan maupun anak didik seperti yang dikemukakan oleh Pidarta (1988) dalam Sardiman (2005: 72). Ada beberapa faktor yang dapat mempengaruhi kinerja guru dalam melaksanakan tugasnya yaitu : a ) Kepemimpinan kepala sekolah, b ) Iklim sekolah, c ) Harapan-harapan, dan d ) Kepercayaan personalia sekolah. Kinerja guru juga dipengaruhi oleh iklim sekolah. Iklim sekolah adalah suasana bekerja, belajar, berkomunikasi, dan bergaul dalam organisasi pendidikan (Pidarta 1988: 176). Dengan terciptanya iklim sekolah yang kondusif, maka guru akan merasa nyaman dalam bekerja dan terpacu untuk bekerja lebih baik. Hal tersebut mencerminkan bahwa suasana sekolah yang kondusif sangat mendukung peningkatan kinerja guru, sehingga diharapkan menghasilkan prestasi belajar siswa yang optimal. Berdasarkan hal tersebut di atas maka penulis tertarik untuk meneliti atau mengkaji lebih dalam tentang: "Pengaruh Kinerja Mengajar Guru dan Iklim Sekolah terhadap Prestasi Belajar Siswa (Studi Deskriptif di MI Kelompok Kerja Madrasah Cipaku)".

Sejalan dengan masalah penelitian yang telah dirumuskan di atas, maka tujuan penelitian ini adalah ingin mengetahui:

1. Pengaruh kinerja mengajar guru terhadap prestasi belajar siswa.

2. Pengaruh iklim sekolah terhadap prestasi belajar siswa.

3. Pengaruh kinerja mengajar guru dan iklim sekolah terhadap prestasi belajar siswa. 


\section{METODE PENELITIAN}

\section{Objek Penelitian}

Dalam penelitian ini, yang menjadi objek penelitian adalah Kinerja Mengajar Guru $\left(\mathrm{X}_{1}\right)$ dan Iklim Sekolah $\left(\mathrm{X}_{2}\right)$, Prestasi Belajar Siswa (Y). Berdasarkan ketiga objek penelitian ini, maka dapat dianalisis sebagai berikut: pertama: Pengaruh kinerja mengajar guru terhadap prestasi belajar siswa, kedua: Pengaruh iklim sekolah terhadap prestasi belajar siswa; dan Ketiga: Pengaruh kinerja mengajar guru dan iklim sekolah terhadap prestasi belajar siswa. Adapun yang menjadi unit analisis dalam penelitian adalah guru di KKM Cipaku.

\section{Metode dan Desain Penelitian}

Metode penelitian yang akan digunakan dalam penyusunan tesis ini adalah deskriptif. Penelitian deskriptif adalah suatu metode yang menggambarkan apa yang dilakukan berdasarkan fakta-fakta atau kejadian-kejadian pada objek yang diteliti, untuk kemudian diolah menjadi data dan selanjutnya dilakukan suatu analisis sehingga pada akhirnya dihasilkan suatu kesimpulan (lihat (Apriyanto \& Anum, 2018; Ayu et al., 2020; Dalman et al., 2020; Kusuma \& Apriyanto, 2018; Subyantoro \& Apriyanto, 2020). Desain penelitian dapat digambarkan sebagai berikut:

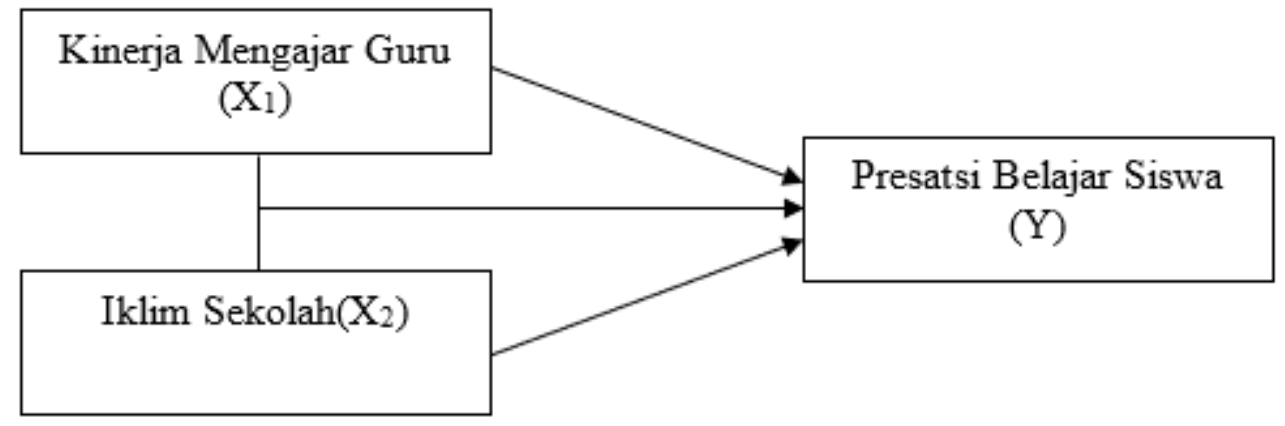

\section{Operasionalisasi Variabel}

Pada penelitian ini ditetapkan tiga jenis variable yang akan diukur, yaitu :

1. Variabel bebas (independent variable) dengan notasi (X) yaitu variabel yang memberikan pengaruh kepada variabel terikat. Notasi $(\mathrm{X})$ adalah kinerja mengajar guru $\left(\mathrm{X}_{1}\right)$ dan Iklim Sekolah $\left(\mathrm{X}_{2}\right)$.

2. Variabel terikat (Dependend Variable) dengan Notasi (Y) yaitu variabel yang dipengaruhi atau yang menjadi akibat karena adanya variable bebas. Variabel tersebut prestasi belajar siswa.

Tabel 3.1

Operasionalisasi Variabel Penelitian

\begin{tabular}{|l|l|l|l|c|}
\hline Variabel & Konsep Variabel & \multicolumn{1}{|c|}{ Dimensi } & \multicolumn{1}{|c|}{ Indikator } & Skala \\
\hline Kinerja & & RPP & $\begin{array}{l}1 . \quad \begin{array}{l}\text { RPP dijabarkan dari } \\
\text { silabus }\end{array} \\
\text { Ordinal }\end{array}$ \\
\hline
\end{tabular}




\begin{tabular}{|c|c|c|c|c|}
\hline Variabel & Konsep Variabel & Dimensi & Indikator & Skala \\
\hline \multirow[t]{2}{*}{$\begin{array}{l}\text { Mengajar } \\
\text { Guru }\left(X_{1}\right)\end{array}$} & \multirow{2}{*}{$\begin{array}{l}\text { Kinerja guru yang } \\
\text { menggambarkan } \\
\text { guru sebagai } \\
\text { pengajar dan } \\
\text { pelaksana } \\
\text { administrasi } \\
\text { mengajarnya } \\
\text { yang dilandasi } \\
\text { etos kerja yang } \\
\text { tinggi dan disiplin } \\
\text { profesional guru } \\
\text { berdasarkan } \\
\text { standar proses } \\
\text { pembelajaran. } \\
\text { (Permendiknas } \\
\text { No. } 41 \text { Tahun } \\
\text { 2007) }\end{array}$} & & $\begin{array}{l}\text { 2. Menyusun RPP secara } \\
\text { lengkap dan } \\
\text { sistematis. } \\
\text { 3. RPP disusun untuk } \\
\text { setiap KD. } \\
\text { 4. Guru merancang } \\
\text { penggalan RPP untuk } \\
\text { setiap pertemuan. }\end{array}$ & \\
\hline & & $\begin{array}{l}\text { Pelaksanaan } \\
\text { Proses } \\
\text { Pembelajaran }\end{array}$ & $\begin{array}{l}\text { 1. Guru mengatur } \\
\text { tempat duduk sesuai } \\
\text { karakteristik peserta } \\
\text { didik dan mata } \\
\text { pelajaran; } \\
\text { 2. Volume dan intonasi } \\
\text { suara guru dalam } \\
\text { proses pembelajaran; } \\
\text { 3. Tutur kata guru; } \\
\text { 4. Guru menyesuaikan } \\
\text { materi pelajaran } \\
\text { dengan kecepatan } \\
\text { dan kemampuan } \\
\text { belajar peserta didik; } \\
\text { 5. Guru menciptakan } \\
\text { ketertiban, } \\
\text { kedisiplinan, } \\
\text { kenyamanan; } \\
\text { Guru memberikan } \\
\text { penguatan dan } \\
\text { umpan balik; } \\
\text { 7. Guru menghargai } \\
\text { peserta didik; } \\
\text { Guru menghargai } \\
\text { pendapat peserta } \\
\text { didik; } \\
\text { Guru memakai } \\
\text { pakaian yang sopan, } \\
\text { bersih, dan rapi; } \\
\text { 10. Pada tiap awal } \\
\text { semester, guru } \\
\text { menyampaikan } \\
\text { silabus mata } \\
\text { pelajaran yang } \\
\text { diampunya; dan } \\
\text { 11. Guru memulai dan } \\
\text { mengakhiri proses } \\
\text { pembelajaran sesuai } \\
\text { dengan waktu yang } \\
\text { dijadwalkan. }\end{array}$ & \\
\hline
\end{tabular}




\begin{tabular}{|c|c|c|c|c|}
\hline Variabel & Konsep Variabel & Dimensi & Indikator & Skala \\
\hline & & $\begin{array}{l}\text { Penilaian Hasil } \\
\text { Pembelajaran }\end{array}$ & $\begin{array}{l}\text { 1. Dilakukan oleh guru } \\
\text { terhadap hasil } \\
\text { pembelajaran untuk: } \\
\text { a. Mengukur tingkat } \\
\text { pencapaian } \\
\text { kompetensi } \\
\text { peserta didik, } \\
\text { b. Bahan } \\
\text { penyusunan } \\
\text { laporan kemajuan } \\
\text { hasil belajar, dan } \\
\text { c. Memperbaiki } \\
\text { proses } \\
\text { pembelajaran. } \\
\text { 2. Dilakukan secara: } \\
\text { a. Konsisten, } \\
\text { b. Sistematik, dan } \\
\text { c. Terprogram. } \\
\text { 3. Menggunakan: } \\
\text { a. tes dan non-tes } \\
\text { b. bentuk tertulis } \\
\text { atau lisan, } \\
\text { c. pengamatan } \\
\text { kinerja, } \\
\text { d. pengukuran } \\
\text { sikap, } \\
\text { e. penilaian hasil } \\
\text { karya (tugas, } \\
\text { proyek dan/atau } \\
\text { produk) } \\
\text { f. portofolio, dan } \\
\text { g. penilaian diri. } \\
\text { Penilaian hasil } \\
\text { pembelajaran } \\
\text { menggunakan; } \\
\text { a. Standar } \\
\text { Penilaian } \\
\text { Pendidikan dan } \\
\text { b. Panduan } \\
\text { Penilaian } \\
\text { Kelompok Mata } \\
\text { Pelajaran. }\end{array}$ & \\
\hline $\begin{array}{l}\text { Iklim } \\
\text { Sekolah } \\
\left(\mathrm{X}_{2}\right)\end{array}$ & $\begin{array}{l}\text { Kondisi kultural } \\
\text { organisasi } \\
\text { sekolah yang } \\
\text { memberikan }\end{array}$ & $\begin{array}{l}\text { Lingkungan } \\
\text { fisik sekolah }\end{array}$ & $\begin{array}{l}\text { 1. Kebersihan ruangan } \\
\text { dan halaman } \\
\text { 2. Kesehatan personil } \\
\text { 3. Ketertiban dalam } \\
\text { melaksanakan aturan }\end{array}$ & \\
\hline
\end{tabular}




\begin{tabular}{|c|c|c|c|c|}
\hline Variabel & Konsep Variabel & Dimensi & Indikator & Skala \\
\hline & $\begin{array}{l}\text { ruang dalam } \\
\text { mengatur } \\
\text { hubungan sosial } \\
\text { orang-orang yang } \\
\text { terlibat dalam } \\
\text { pendidikan/ } \\
\text { pembelajaran. } \\
\text { (Hoy dan Miskel, } \\
\text { 2001:132) }\end{array}$ & & $\begin{array}{l}\text { 4. Interaksi kerjasama } \\
\text { antar sekolah dengan } \\
\text { masyarakat. } \\
\text { 5. Bukti monumental } \\
\text { hasil kerjasama } \\
\text { sekolah dengan } \\
\text { masyarakat } \\
\text { 6. Pernyataan bersama } \\
\text { saling membutuhkan } \\
\text { antar sekolah dan } \\
\text { masyarakat. }\end{array}$ & \\
\hline & & $\begin{array}{l}\text { Lingkungan } \\
\text { non fisik }\end{array}$ & 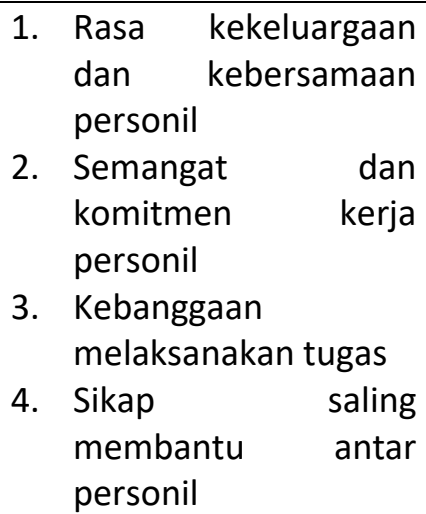 & \\
\hline \multirow[t]{2}{*}{$\begin{array}{l}\text { Prestasi } \\
\text { Belajar } \\
\text { Siswa (Y) }\end{array}$} & \multirow{2}{*}{$\begin{array}{l}\text { Prestasi belajar } \\
\text { siswa merupakan } \\
\text { prestasi yang } \\
\text { dicapai peserta } \\
\text { didik baik } \\
\text { prestasi } \\
\text { akademik } \\
\text { maupun non } \\
\text { akademik } \\
\text { (Widodo, 2008:5) }\end{array}$} & $\begin{array}{l}\text { Prestasi } \\
\text { Akademik }\end{array}$ & $\begin{array}{l}\text { 1. Nilai ulangan umum } \\
\text { yang dicapai siswa. } \\
\text { 2. Nilai ujian } \\
\text { 3. Karya ilmiah remaja } \\
\text { 4. Lomba-lomba } \\
\text { akademik } \\
\text { 5. Kuantitas lulusan } \\
\text { 6. Kualitas lulusan }\end{array}$ & Ordinal \\
\hline & & $\begin{array}{l}\text { Prestasi Non- } \\
\text { Akademik }\end{array}$ & $\begin{array}{l}\text { 1. Olahraga } \\
\text { 2. Kesenian } \\
\text { 3. Keterampilan } \\
\text { 4. Pramuka }\end{array}$ & \\
\hline
\end{tabular}

\section{Populasi dan Sampel Penelitian}

Populasi dalam penelitian ini adalah sejumlah MI KKM Cipaku yang berjumlah 12 madrasah dengan jumlah guru sebanyak 180 orang, dengan jumlah sampel 171 orang (tingkat pengambilan sampel 5\%).

\section{Teknik Pengumpulan Data}

Untuk memperoleh ketiga data penelitian, penulis menggunakan kuesioner berupa skala likert, masing-masing 5 pilihan (option). Angket dalam penelitian ini digunakan untuk mengukur variabel Kinerja Mengajar Guru $\left(\mathrm{X}_{1}\right)$, Iklim Sekolah $\left(\mathrm{X}_{2}\right)$, dan Prestasi Belajar Siswa (Y). 


\section{Teknik Analisis Data dan Uji Hipotesis}

Semua data yang telah terkumpul dianalisis sehingga dapat diketahui makna dari data yang berhasil dikumpulkan dan hasil penelitiannyapun akan dapat diketahui. Dalam pelaksanaan pengolahan data melalui bantuan computer dengan program SPSS 17.0 (Statistical Product and Service Solutions), dengan langkah-langkah sebagai berikut:

1. Menyeleksi data agar dapat diolah lebih lanjut dengan memeriksa setiap jawaban responden sesuai dengan kriteria yang telah ditetapkan.

2. Menentukan bobot nilai setiap kemungkinan jawaban pada setiap item, variabel penelitian dengan menggunakan skala penilaian yang telah ditentukan, kemudian menentukan skornya. Melihat deskripsi variabel yang diamati, maka setiap indikator dicari ukuran statistik yang menunjukan gejala pusat pengelompokan (measure of central tendency).

3. Menganalisa besarnya pengaruh dihitung dengan cara membandingkan jumlah skor mentah dengan skor kriterium, dinyatakan dalam persen (\%). Selanjutnya untuk menguji signifikansi digunakan uji t satu sampel (one sample t tes).

4. Untuk mengetahui hubungan fungsional antar variabel digunakan metode Regresi yang digunakan adalah regresi linear sederhana dan regresi linear ganda.

Menguji hipotesis, ada beberapa hal yang perlu dikerjakan dahulu, yaitu mendeskripsikan data, menghitung persyaratan analisis, kemudian dilanjutkan dengan menguji hipotesis. Statistik yang digunakan untuk menguji tiga hipotesis adalah uji t satu sampel (one sample t tes).

\section{HASIL PENELITIAN DAN PEMBAHASAN}

Pengujian hipotesis dilakukan guna mengetahui apakah hipotesis yang diajukan dalam penelitian ini dapat diterima atau ditolak. Berdasarkan hasil uji prasyarat ternyata pengujian hipotesis dapat dilakukan, sebab sejumlah persyaratan yang ditentukan untuk pengujian hipotesis, yaitu normalitas masing-masing varibel yang diteliti berdistribusi normal.

\section{Pengaruh Kinerja Mengajar Guru terhadap Prestasi Belajar Siswa}

Pengujian terhadap hubungan antara $\mathrm{X}_{1}$ dengan $\mathrm{Y}$ dilakukan dengan menggunakan uji korelasi Product Moment Pearson's. Uji ini dilakukan karena masing-masing variabel yang diuji memenuhi syarat untuk pengujian korelasi ini. Hasil pengolahan statistic dengan bantuan program SPSS 17.0 hubungan kedua variabel antara $\mathrm{X}_{1}$ dengan $\mathrm{Y}$ bahwa angka koefisien korelasi (r) sebesar 0,487 dengan kategori korelasi cukup/sedang. Dengan demikian dapat dikatakan bahwa kinerja mengajar guru dengan prestasi belajar siswa termasuk dalam kategori korelasi cukup/sedang. Kemudian dari tabel tersebut diketahui bahwa $\mathrm{r}^{2}$ sebesar $(0,302)^{2}=0,091$ merupakan indeks determinasi atau persentase pengaruh $\mathrm{X}_{1}$ terhadap $\mathrm{Y}$. Dengan demikian dapat dinyatakan bahwa kinerja mengajar guru berpengaruh sebesar 9,1\% terhadap prestasi belajar siswa sedangkan 90,9\% dipengaruhi oleh faktor lain. Selajutnya bahwa, nilai thitung sebesar 4.531 dengan df $1=$ derajat kebebasan pembilang 1 dan df $2=$ derajat kebebasan penyebut 170 nilai tabel 
$=2,228$ pada taraf signifikansi $0,05\left(\mathrm{t}_{\text {hitung }}>\mathrm{t}_{\text {tabel }}\right)$ dengan nilai signifikan sebesar 0,000 $(0,000<0,05)$ menunjukan model regresi signifikan artinya Ha diterima dan Ho ditolak. Dengan demikian hipotesis pertama penelitian ini yang menyatakan: "Kinerja mengajar guru berpengaruh positif terhadap prestasi belajar siswa." diterima.

\section{Pengaruh Iklim Sekolah terhadap Prestasi Belajar Siswa}

Pengujian terhadap hubungan antara $\mathrm{X}_{2}$ dengan $\mathrm{Y}$ dilakukan dengan menggunakan uji korelasi Product Moment Pearson's. Uji ini dilakukan karena masing-masing variabel yang diuji memenuhi syarat untuk pengujian korelasi ini. Hasil pengolahan statistic dengan bantuan program SPSS 17.0 hubungan kedua variabel antara $\mathrm{X}_{1}$ dengan $\mathrm{Y}$ bahwa angka koefisien korelasi (r) sebesar 0,427 dengan kategori korelasi cukup/sedang. Dengan demikian dapat dikatakan bahwa iklim sekolah dan prestasi belajar siswa termasuk dalam kategori korelasi cukup/sedang. Kemudian dari tabel tersebut diketahui bahwa $r^{2}$ sebesar $(0,320)^{2}=0,102$ merupakan indeks determinasi atau persentase pengaruh $\mathrm{X}_{2}$ terhadap $\mathrm{Y}$. Dengan demikian dapat dinyatakan bahwa iklim sekolah berpengaruh sebesar 10,2\% terhadap prestasi belajar siswa sedangkan 89,8 dipengaruhi oleh faktor lain. Kemudian, nilai thitung sebesar 4,344 dengan df1=derajat kebebasan pembilang 1 dan df $2=$ derajat kebebasan penyebut 170 nilai $t_{\text {tabel }}=2,228$ pada taraf signifikansi 0,05 ( $\left.t_{\text {hitung }}>t_{\text {tabel }}\right)$ dengan nilai signifikan sebesar $0,000 \quad(0,000<0,05)$ menunjukan model regresi signifikan artinya Ha diterima dan Ho ditolak. Dengan demikian hipotesis kedua penelitian ini yang menyatakan: "Iklim sekolah berpengaruh positif terhadap prestasi belajar siswa." diterima.

\section{Pengaruh Kinerja Mengajar Guru dan Iklim Sekolah terhadap Prestasi Belajar Siswa}

Pengujian terhadap hubungan antara $\mathrm{X}_{1}$ dan $\mathrm{X}_{2}$ dengan $\mathrm{Y}$ dilakukan dengan menggunakan uji korelasi Product Moment Pearson's. Uji ini dilakukan karena masingmasing variabel yang diuji memenuhi syarat untuk pengujian korelasi ini. Hasil pengolahan statistik dengan bantuan program SPSS 17.0 hubungan ketiga variabel antara $\mathrm{X}_{1}, \mathrm{X}_{2}$ dengan $\mathrm{Y}$ diperoleh angka koefisien korelasi (r) sebesar 0,785, pada korelasi kuat dengan demikian kinerja mengajar guru dan iklim sekolah dengan prestasi belajar siswa mempunyai hubungan yang kuat. Kemudian dari tabel tersebut diketahui bahwa koefisien Adjusted $R$ Square sebesar 0,516 merupakan indeks determinasi atau persentase pengaruh $\mathrm{X}_{1}$ dan $\mathrm{X}_{2}$ terhadap $\mathrm{Y}$. Dengan demikian dapat dinyatakan bahwa kinerja mengajar guru dan iklim sekolah berpengaruh sebesar 51,6\% terhadap prestasi belajar siswa sedangkan $48,4 \%$ pengaruhnya oleh faktor lain, misalnya sarana dan prasarana, sistem informasi manajemen, budaya organisasi, gaya kepemimpinan dan lainnya. Selanjutnya nilai $F_{\text {hitung }}$ sebesar 16,219 dengan df1=derajat kebebasan pembilang 1 dan df $2=$ derajat kebebasan penyebut 169 nilai $F_{\text {tabel }}=6,71$ (lampiran 2.17) pada taraf signifikansi 0,05 $\left(F_{\text {hitung }}>F_{\text {tabel }}\right)$ dengan nilai signifikan sebesar $0,000(0,000<0,05)$ menunjukkan model regresi signifikan artinya Ha diterima dan Ho ditolak. Dengan demikian hipotesis ketiga penelitian ini yang menyatakan: "Kinerja mengajar guru dan iklim sekolah berpengaruh positif terhadap prestasi belajar siswa." diterima. 


\section{Pembahasan}

Berdasarkan hasil perhitungan statistik terhadap data hasil penelitian dapat ditafsirkan pengaruh masing-masing variabel sebagai berikut:

\section{Pengaruh Kinerja Mengajar Guru terhadap Prestasi Belajar Siswa}

Kinerja mengajar guru di MI KKM Cipaku berada pada kriteria tinggi, namun demikian ada indikator yang perlu ditingkatkan yaitu mengatur tempat duduk sesuai karakteristik peserta didik dan mata pelajaran. Hasil uji hipotesis menunjukkan bahwa kinerja mengajar guru berpengaruh positif terhadap prestasi belajar siswa. Ini berarti semakin baik kinerja mengajar guru maka cenderung semakin meningkat prestasi belajar siswa. Proses belajar mengajar merupakan salah satu hal utama dalam menjawab semua permasalahan tersebut. Proses belajar mengajar tersebut ditopang oleh tiga komponen yaitu siswa, guru dan peralatan serta perlengkapan. Sardiman (2005: 125) mengemukakan guru adalah salah satu komponen manusiawi dalam proses belajar mengajar, yang ikut berperan dalam usaha pembentukan sumber daya manusia yang potensial di bidang pembangunan. Oleh karena itu, guru yang merupakan salah satu unsur di bidang kependidikan harus berperan secara aktif dan menempatkan kedudukannya sebagai tenaga profesional, sesuai dengan tuntutan masyarakat yang semakin berkembang. Dalam hal ini guru tidak semata-mata sebagai pengajar yang melakukan transfer ilmu pengetahuan, tetapi juga sebagai pendidik yang melakukan transfer nilai-nilai sekaligus sebagai pembimbing yang memberikan pengarahkan dan menuntun siswa dalam belajar.

Kelengkapan dari jumlah tenaga pengajar, dan kualitas dari guru tersebut akan mempengaruhi keberhasilan siswa dalam belajar, yang berujung pada peningkatan mutu pendidikan. Untuk itu guru dituntut lebih profesional dalam menjalankan tugasnya. Tugas Keprofesionalan Guru menurut Undang-Undang Republik Indonesia Nomor 14 Tahun 2005 pasal 20 (a) Tentang Guru dan Dosen adalah "Merencanakan pembelajaran, melaksanakan proses pembelajaran yang bermutu, serta menilai dan mengevaluasi hasil pembelajaran." Tugas pokok guru tersebut yang diwujudkan dalam kegiatan belajar mengajar serta tugas-tugas guru dalam kelembagaan marupakan bentuk kinerja guru. Apabila kinerja guru meningkat, maka berpengaruh pada peningkatan kualitas keluaran atau outputnya. Oleh karena itu perlu dukungan dari berbagai pihak sekolah untuk meningkatkan kinerja guru.

\section{Pengaruh Iklim Sekolah terhadap Prestasi Belajar Siswa}

Iklim sekolah di MI KKM Cipaku berada pada kriteria kondusif, namun demikian ada indikator yang perlu ditingkatkan yaitu bukti monumental hasil kerjasama sekolah dengan masyarakat. Hasil uji hipotesis menunjukkan bahwa iklim sekolah berpengaruh positif terhadap prestasi belajar siswa. Ini berarti semakin kondusif iklim sekolah maka cenderung semakin meningkat prestasi belajar siswa.

Iklim organisasi sekolah sangat penting untuk dipelihara dan ditumbuh kembangkan dengan baik, agar (1) mampu menjadi motifasi dalam produktivitas kinerja guru, (2) dapat menjaga berlangsungnya hubungan komunikasi timbal balik diantara 
pihak yang turut serta dalam pendidikan serta dalam pendidikan dalam mengembangkan proses pembelajaran dan peningkatan mutu layanan pendidikan, dan (3) dapat mempertebal kepercayaan terhadap hasil pendidikan. Ikim oganisasi sekolah pada dasarnya tidak terlepas dan bahkan terbentuk oleh iklim organisasi sekolah dan lingkungan kerja. Mashall Poole (dalam Hoy dan Miskel. 2001:189), menggambarkan bahwa iklim organisasi sekolah merupakan hasil kesepakatan-kesepakatan, yaitu:

(1) iklim organisasi berkaitan dengan kepemilikan yang merupakan ciri keseuruhan organisasi termasuk sumbu intnya, (2) iklim organisasi merupakan gambaran keadaan suatu unit organisasi dari para penilainya, (3) iklim organisasi berasal dari prakik-praktik ruin organisasi yang penting bagi organisasinya dan anggotanya, dan (4) iklim organisasi mempengaruhi perilaku dan sikap anggota organisasi.

Santoso dalam Sagala (2007:78), menggambarkan bahwa "Iklim organisasi sekolah pada hakikatnya tidak berbeda dengan iklim organisasi sekolah dan lingkungan kerja yang senantisa dipengaruhi oleh berbagai faktor lingkungan internal dan eksternal baik lingkungan fisik maupun lingkungan non fisik." Aspek-aspek lingkungan fisik yang mempengaruhi ikilm organisasi sekolah menurut Santoso dalam Sagala (2007:78) meliputi: (1) kebersihan ruangan dan halaman, (2) kesehatan personil (guru, tata usaha dan siswa), (3) ketertiban dalam melaksanakan aturan atau kesepakatan bersaana, (4) interaksi kerjasama antar sekolah denagan masyarakat, (5) bukti monumental hasil kerja sama sekolah dengan masyarakat, dan (6) pernyataan bersama saling membutuhkan saling membantu antar sekolah dan masyarakat. Sedangkan aspek-aspek non fisik, meliputi (1) rasa keluarga dan kebersamaan personil, (2) semangat dan komitmen kerja personil, (3) kebangaan melaksanakan tugas, dan (4) saikap saling membantu antar personil.

Dengan demikian pengukuran iklim organisasi sekolah akan dilakukan melalui beberapa indikator yang terkait dan mempengaruhi pembelajaran di sekolah, meliputi: (1) kondisi fisik pekerjaan, meliputi aspek sarana dan prasarana, kesejaterahan dan penghargaan, (2) kondisi sosial pekerjaan meliputi aspek keprcayaan, desain pekerjaan, pengendalian, iklim kepemimpinan, komunikasi dan interaksi, perumusan tujuan, dan penetapan kebijakan serta pengambilan keputusan.

\section{Pengaruh Kinerja Mengajar Guru dan Iklim Sekolah terhadap Prestasi Belajar Siswa}

Prestasi belajar siswa di KKM Cipaku berada pada kriteria berprestasi, namun demikian ada beberapa indikator yang harus ditingkatkan yaitu karya ilmiah remaja, lomba-lomba akademik, olahraga, kesenian, dan pramuka. Hasil uji hipotesis menunjukkan bahwa kinerja mengajar guru dan iklim sekolah berpengaruh positif terhadap prestasi belajar siswa. Ini berarti semakin baik kinerja mengajar guru dan semakin kondusif iklim sekolah maka cenderung semakin meningkat prestasi belajar siswa. Berhasil tidaknya perbuatan belajar itu tergantung kepada macam-macam faktor. Ngalim Purwanto (2002:102) membedakan faktor-faktor yang mempengaruhi prestasi belajar menjadi dua golongan, yaitu: “(1) Faktor yang ada pada diri organisme itu sendiri 
yaitu kita sebut faktor individual. (2) Faktor yang ada di luar individu yang kita sebut faktor sosial." Berdasarkan pendapat tersebut dapat disimpulkan bahwa berhasil tidaknya perbuatan belajar sangat dipengaruhi oleh faktor-faktor internal bersumber dari siswa dengan segala aspeknya dan faktor-faktor eksternal yaitu yang bersumber dari luar siswa juga dengan segala aspeknya. Prestasi belajar yang dicapai pada hakikatnya merupakan hasil interaksi antara berbagai faktor tersebut misalnya kinerja mengajar guru.

Adapun standar untuk pengukuran mutu lulusan, Gordon (dalam Mulyasa, 2002: 38) menjelaskan beberapa aspek atau ranah yang terkandung dalam konsep kompetensi siswa yang mendasari peraihan prestasi hasil belajar yaitu sebagai berikut: (1) Pengetahuan (knowledge) yaitu kesadaran dalam bidang kognitif, misalnya seorang guru mengetahui cara melakukan identifikasi kebutuhan belajar dan bagaimana melakukan pembelajaran terhadap peserta didik sesuai dengan kebutuhannya. (2) Pemahaman (understanding) yaitu kedalaman kognitif, dan afektif yang dimiliki oleh individu. (3) Kemampuan (skill) adalah sesuatu yang dimiliki oleh individu untuk melakukan tugas atau bentuk pekerjaan yang dibebankan kepadanya. (4) Nilai (value) adalah suatu standar perilaku yang telah diyakini dan secara psikologis telah menyatu dalam diri seseorang. (5) Sikap (attitude) yaitu perasaaan (senang tidak senang, suka tidak suka) atau reaksi terhadap suatu rangsangan yang datang dari luar. (6) Minat (interest) adalah kecendenungan seseorang untuk melakukan sesuatu perbuatan baik. Dengan demikian mutu lulusan dapat dikatagorikan menjadi dua arah penelaahan, diantaranya adalah mutu dari segi akademik dan mutu dari segi non akademis.

\section{SIMPULAN}

Berdasarkan pembahasan yang telah dilakukan, maka dapat diambil beberapa kesimpulan sesuai dengan permasalahan yang diteliti, sebagai berikut:

1. Kinerja mengajar guru di MI KKM Cipaku berada pada kriteria tinggi, namun demikian ada indikator yang perlu ditingkatkan yaitu mengatur tempat duduk sesuai karakteristik peserta didik dan mata pelajaran. Selanjutnya kinerja mengajar guru berpengaruh positif terhadap prestasi belajar siswa. Ini berarti semakin tinggi kinerja mengajar guru maka cenderung semakin meningkat prestasi belajar siswa.

2. Iklim sekolah di MI KKM Cipaku berada pada kriteria kondusif, namun demikian ada indikator yang perlu ditingkatkan yaitu bukti monumental hasil kerjasama sekolah dengan masyarakat. Selanjutnya iklim sekolah berpengaruh positif terhadap prestasi belajar siswa. Ini berarti semakin kondusif iklim sekolah maka cenderung semakin meningkat prestasi belajar siswa.

Prestasi belajar siswa di KKM Cipaku berada pada kriteria berprestasi, namun demikian ada beberapa indikator yang harus ditingkatkan yaitu karya ilmiah remaja, lomba-lomba akademik, olahraga, kesenian, dan pramuka. Selanjutnya kinerja mengajar guru dan iklim sekolah berpengaruh positif terhadap prestasi belajar siswa. Ini berarti 
semakin tinggi kinerja mengajar guru dan semakin kondusif iklim sekolah maka cenderung semakin meningkat prestasi belajar siswa.

\section{DAFTAR PUSTAKA}

Adikusumo, Amir HD, (1998). Mamajemen Pola Terpadu. Jakarta: Lembaga Administrasi Negara-RI.

Apriyanto, S., \& Anum, A. (2018). Gender Dynamics on Speaking Interaction in the College Classroom. Jurnal Smart, 4(2), 73. https://doi.org/10.26638/js.692.203x

Arikunto, S, (2001). Pengaruh Hasil Tes Akademik Terhadap Kepribadian Mahasisw, Laporan Penelitian, tidak diterbitkan.

Atmosudirdjo. (2001). Pedoman Penyusun Laporan Akuntabilitas Kinerja Instansi Pemerintah. Jakarta: Lembaga Administrasi Negara.

Ayu, I., Erlina, H., Santoso, D., \& Apriyanto, S. (2020). Perspective of Parents of Online Learning in Pandemic Covid-19. Journal of Research in Business, Economics, and Education, 2(6), 1346-1350.

Bernadin and Rusell, (1992). Human Resources Management an Experiental Approach. Singapore: Mac Graw Hill. Book CO.

Betha, N S, (2004). Sistem Pembelajaran KBK Terhadap Motivasi Belajar Para Peserta Didik Pada Bidang Studi Fisika (online). Tersedia : http://artikel.us/art05-57.html. [23 Mei 2021]

Campbell, R.F at al, (1980). Introduction to Educational Administration, Boston: Allyn Bacon, Inc.

Dalman, Hesti, \& Apriyanto, S. (2020). Conversational implicature: A pragmatic study of "our conversation" in learning at university. International Journal of Psychosocial Rehabilitation, 24(8), 4332-4340. https://doi.org/10.37200/IJPR/V24I8/PR280450

Davis, Keith, \& Newstorm, W., John. (2000). Human Behaviour At Work: Organizational Behaviour, New York: Mc Graw Hill International.

Depdikbud, 1995, Kamus Besar Bahasa Indonesia, Jakarta: Balai Pustaka.

Djam'an Satori, (2008). Prestasi Kerja Guru, tersedia pada http://www.guruvalah.tk. (akses 15 Pebruari 2021)

Donnely, J.H. Gibson, J.L, dan Ivanevic, J.M, (1996). Organisasi (Edisi 2). Jakarta : Bumi Aksara. 
Endro, Bayu. Hubungan Antara Kesesakan yang Terjadi di Dalam Kelas Terhadap Prestasi Belajar Siswa (online). Tersedia : http://library.gunadarma.ac.id. [23 Mei 2021]

Engkoswara, (2001). Menuju Indonesia Modern 2020, Bandung: Yayasan Amal Keluarga.

Hersey, Paul dan Blanchard, K.H, (1998). Manajement of Organization Behavior, New York:Engliwood clifs.

Hoy, Wayne K dan Mischel, (2001). Education Administration: Theory Research and Practice, Singapore: Mc Gram-Hill co.

Kusuma, H. A., \& Apriyanto, S. (2018). Strategy on Developing English Learning Material for Specific Purposes. IJECA (International Journal of Education and Curriculum Application), 1(3), 39. https://doi.org/10.31764/ijeca.v1i3.2144

Listiani, (2005). Pengaruh Kinerja Mengajar Guru dan Iklim Sekolah terhadap Prestasi Belajar Siswa Kelas XI SMK Negeri 5 Semarang, Jurnal Unes Semarang.

Malayu, H. S.P.Hasibuan, (1996). Manajemen Suber Daya Manusia, Jakarata: Bumi Aksara. (2007). Organisasi dan Motivasi, Jakarata: Bumi Aksara.

Mulyasa, E, (2002). Kurikulum Berbasis Kompetensi (KBK). Bandung. PT.Rosdakarya. , (2004). Menjadi Guru Profesional. Bandung. Remaja Rosdakarya.

Nasution, Muhamad, (2006). Manajemen Mutu Terpadu, Jakarta:Galia Indah

Permendiknas No. 41 Tahun 2007 Tentang Standar Proses Pembelajaran

Pidarta, M, (1988). Pemikiran Tentang Supervisi Pendidikan, Surabaya: Sarana Press.

Purwanto, Ngalim, (2002). Administrasi dan Supervisi Pendidikan, Bandung: PT. Rosda Karya.

Rianto, Slamet, (2009). Hubungan Komitmen Organisasi dan Kompetensi Guru dengan Kinerja Guru (Studi Korelasional di SD-UPTD Kecamatan Arjawinangun Kabupaten Cirebon), jurnal Uswagati Cirebon.

Riduan, (2007). Rumus dan Data Untuk Penelitian, Bandung Alfabeta.

Robbin, S.P, (1991). Organization Behaviour: Controversies an Aplication. London: Prentice Hall International. Inc.

Sagala, S, (2004). Administrasi Pendidikan Kontemporer, Bandung: Alfa Beta. , (2007). Manajemen Strategik dalam Peningkatan Mutu Pendidikan, Bandung: Alfa Beta. 
Santoso, Bambang, (2005). Kontribusi Kemampuan Manajemen Kelas dan Kinerja Mengajar Guru terhadap Prestasi Belajar Siswa (Studi SD Kecamatan Sumedang Selatan Kabupaten Sumedang), jurnal UPI Bandung.

Sardiman, A.M, (2005). Interaksi dan Motivasi Belajar Mengajar, Jakarta: Raja Grafindo Persada.

Sedarmayanti, (2007). Restrukturisasi dan Pemberdayaan Organisasi untuk Menghadapi Dinamika Perubahan Lingkungan. Bandung: Masdar Maju.

Slameto, (2007). Pengaruh Motivasi dan Metode Pembelajaran terhadap Prestasi Belajar Akutansi. tersedian pada www.indoskripsi.com. (Akses tanggal 12 Januari 2021).

Subyantoro, S., \& Apriyanto, S. (2020). Impoliteness in Indonesian Language Hate Speech on Social Media Contained in the Instagram Account. Journal of Advances in Linguistics, 11, 36-46. https://doi.org/10.24297/jal.v11i.8655

Sudrajat, Akhmad, (2008). Kinerja Guru, tersedia: http://akhmadsudrajat. wordpress.com (12 Januari 2021)

Sufyaman, (2004). Kapita Selekta Manajemen Pendidikan, Bandung: Apfabeta.

Sugiyono, (2007). Metode Penelitian Administrasi, Bandung: Alfabeta.

Supriadi, Dedi, (1998). Teori Hierarki Kebutuhan maslow; tersedia : http// organisasi.org/teorihierarki Maslaw. (tanggal, 2 Mei 2021)

Surya, M, (1994). Psikologi Pembelajaran dan Pengajaran. Bandung : Pustaka Bani Quraisi.

Tarigan, D. (2006). Pengaruh Pendekatan Keterampilan Proses Terhadap Prestasi Belajar Siswa Pada Sub Pokok Bahasan Kalor dan Perpindahannya (online). Tersedia : $\underline{\text { http://sps.upi.edu. }}$ [23 Mei 2021]

Udiman, (2010). Kontribusi Kinerja Kepemimpinan Kepala Sekolah dan Motivasi Kerja terhadap Kinerja Mengajar Guru (Studi di SD Kecamatan Baregbeg Kabupaten Ciamis), Tesis Unigal Ciamis tidak diterbitkan.

Undang-Undang No. 20 Tahun 2003, Tentang Sistem Pendidikan Nasional, Jakarta: Departemen Pendidikan Nasional

Undang-Undang RI No. 14 Tahun 2005 Tentang Guru dan Dosen, Jakarta Depdiknas.

Uzer Usman. (1995). Menjadi Guru Profesional. Bandung: Remaja Rosdakarya. , (2006). Menjadi Guru Profesional. Bandung: Remaja Rosdakarya.

Vincent Gaspersz, (2003). Iso 9000:2000 and Continual Quality Improvement. Gramedia Pustaka Umum, Jakarta 
Widodo, Slamet, (2008). Meningkatkan Produktivitas Sekolah, tersedia http://media.diknas.go.id// (Akses tanggal 2 Mei 2021)

Wijaya, Cece, dkk, (2000). Statistika Penelitian. Bandung: PT. Remaja Rosdakarya. 